\title{
The Dawn of Darwinian Fishery Management
}

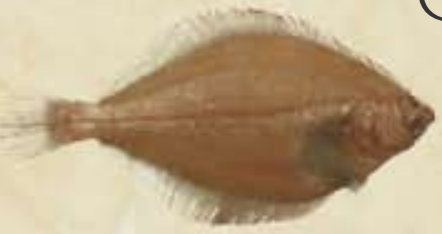

American plaice

Hippoglossoides platessoides

Pliper (Labrador, Ne: ICES).

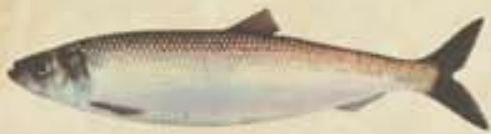

\section{Atlantic herring}

Clupea harengus

Shift of PMRN maturation schedule towards younger ages an smaller sizes (Engelhard and $\mathrm{Hen}$
Institute of Marine Research).

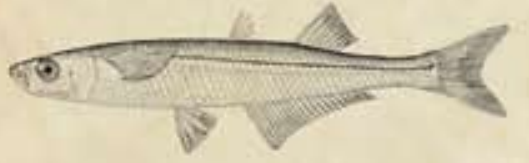

Atlantic silverside

Menidia menidia

Reduced growth rate; decrease in fecundity, egg volume, larval size at hatching, larval growth rate, larval survival, consumption, growth efficiency, food conversion efficiency, willingness to forage under threat of predation, and number of vertebrae (experimental tank populations: Oceans Canada).

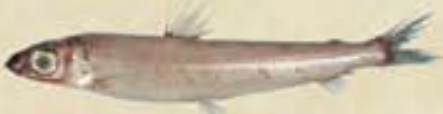

\section{Argentine}

Argentina silus

source: ICES).

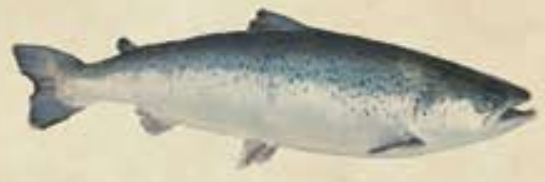

Atlantic salmon

Salmo sala

Reduced annual growth (Godbout River, Quebec, Canada: Bielak and Power 1986), later smolting, lower sea age

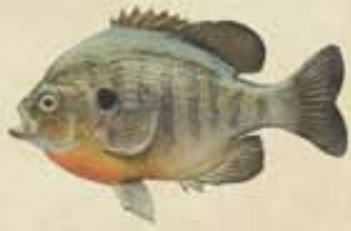

Bluegill

Lepomis macrochirus

Maturation at younger age and lower condition (lakes in Minnesota: Drake et al., 1997; source: Istockphoto).

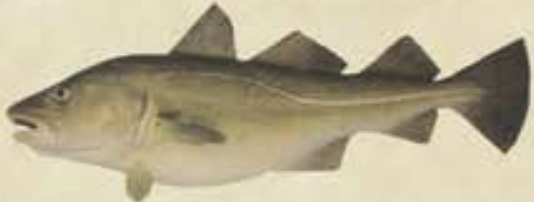

Atlantic cod

Gadus morhua

Maturation at younger age and smaller size (Barents Sea: Gulf of St Lawrence: Beacham 1983a: North Sea Sea to the west of Scotland: Yoneda and Wright 2004: Baltic Sea: Cardinale and Modin 1999), shift of PMRN maturation schedule towards younger ages and smaller sizes (Barents Sea: Heino et al, 2002b; Georges Bank, Gulf of Maine: Barot et al., 2004; Northern cod, Southern Grand Bank, St. Pierre Bank: Olsen et al., 2004, 2005, Baulier Et al., 2006; Grand Bank, St Pierre Bank: B., 2004,2005 Ba Crand Bank. Baulier et al, 2006, Baltic cod Vainikka et al. 2009), reduced annual growth (Southern Gulf of St Iawrence: Swain et al 2007) increased reproductive effort (North Sea, Sea to the west of Scotland: Yoneda and Wright, 2004).

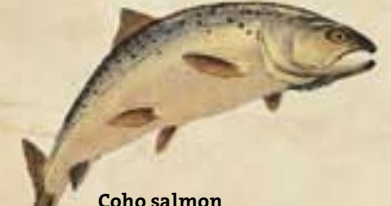

Coho salmon Oncorhynchus kisutch

Maturation at smaller size, reduced annual

growth (British Columbia, Canada: Ricker, 198,

1995; source: NOAA).

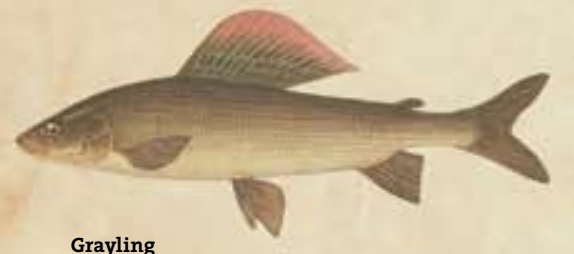

Grayling

Thymallus thymallus

Maturation at younger age and smaller size (lakes in Norwa)

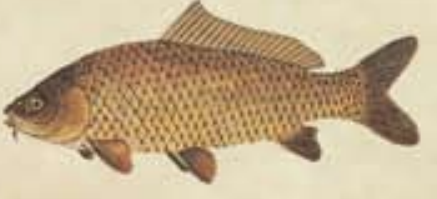

\section{Common carp}

Cyprinus carpio carpio

Maturation at younger age, leaner body, higher

viability, higher escapement (aquaculture lineages,

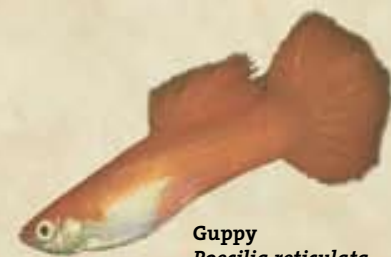

\section{Poecilia reticulata}

Maturation at younger age and smaller size, larger number of offspring, smaller offspring size, higher reproductive effort (comparison of field population
Reznick et al. 1990: Reznick and Ghalambor, 2005: source: www.akwarium.net

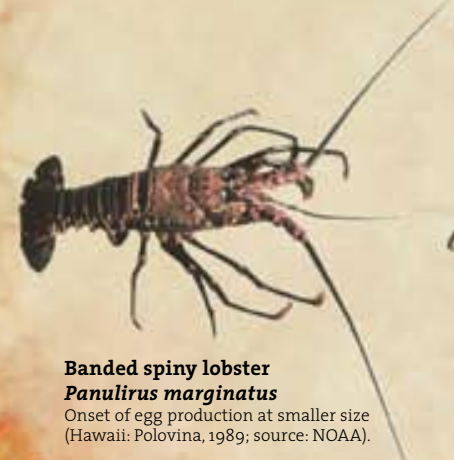

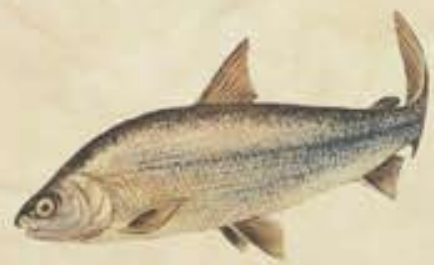

Lake whitefish

Coregonus clupeaformis

Maturation at lower condition, reduced

annual growth, decreased condition

Handford et al., 1977; source: NOAA)

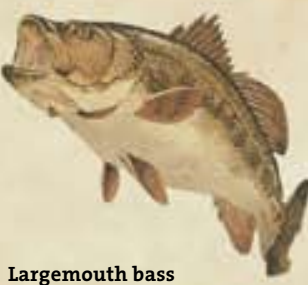

Reduced parental care, reduced resting metabolic rate, poorer swimming performance (experimental field populations: Cooke et al.,

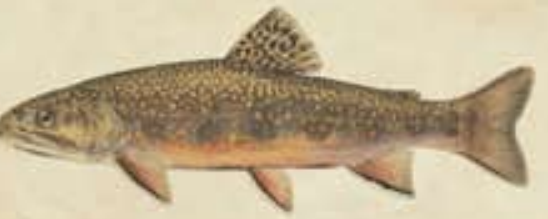

Brook trout

Salvelinus fontinalis

Maturation at younger age, smaller size, and

lower condition (lakes in Canada: Magnan et

2005; source: US Fish and Wildlife Service).

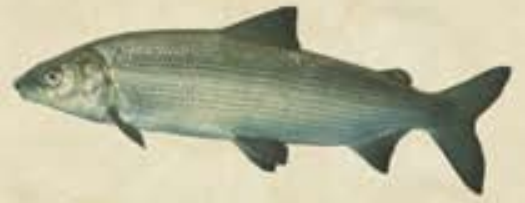

Common whitefish

Coregonus lavaretus

Reduced annual growth (Lake Constance, Germany/Switzerland/ Austria: Thomas and Eckmann, 2007), increased reproductive effort source: Swedish Board of Fisheries).

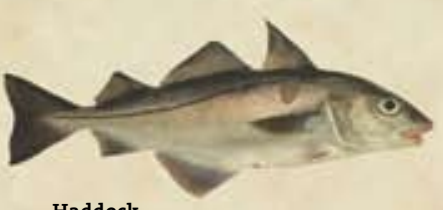

Haddock

Melanogrammus aeglefinus

Maturation at younger age (southern Grand Bank

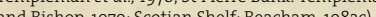
increased rof 2005. Source: Norwegian Institute of Marine Research).

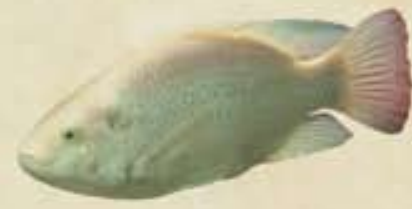

Mozambique tilapia Tilapia mossambica Reduced growth rate

(experimental tank populations: Silliman, 1975: source: Wikimedia). 


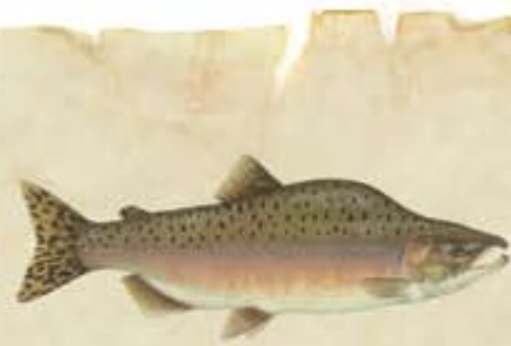

Pink salmon

Oncorhynchus gorbuscha

Maturation at smaller size, reduced annual growth US Fish and Wildlife Service)

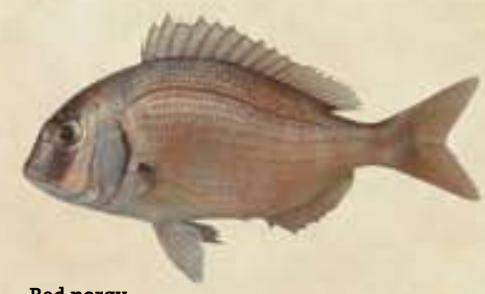

\section{Red porgy}

Pagrus pagrus
Maturation at younger age and smaller siz (South Atlantic Bight: Harris and McGovern, 1997; source: US Fish and Wildlife Service).

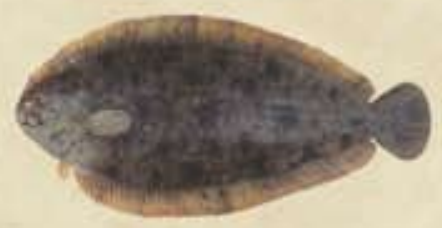

Sole

Solea solea

Shift of PMRN maturation schedule towards younger ages and smaller sizes (Mollet et al., 2007:

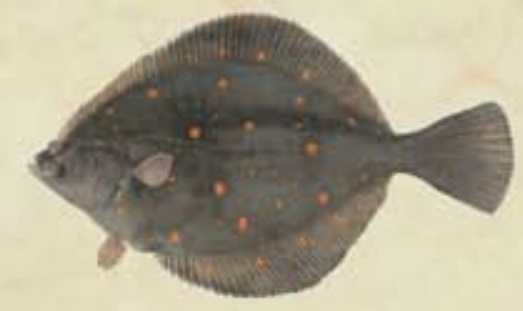

Plaice

Pleuronectes platessa

Maturation at younger age and smaller size (North Sea: Rijnsdorp, 1989, 1993a, 1993b), shift of PMRN maturation schedule towards younger ages and smaller sizes (North Sea: Grift et al., 2003, 2007 Mollet et al., 2007), increased reproductive effort (North Sea: Rijnsdorp, 1991; Rijnsdorp et al, 2005; source: Norwegian Institute of Marine Research).

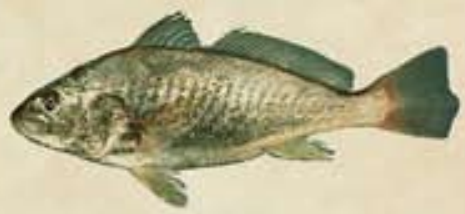

Small yellow croaker

Pseudosciaena polyactis

Maturation at younger age and smaller size

(Yellow Sea: Dieckmann et al, 2005).

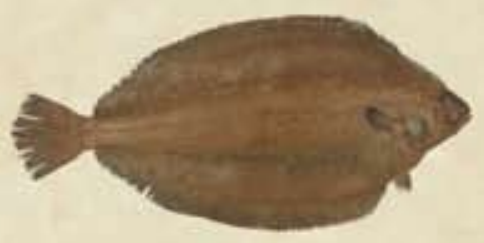

Witch flounder

Glyptocephalus cynoglossus

Maturation at younger age and smaller size

(southern Gulf of St Lawrence, Scotian Shelf: Beacham, 1983f; source: ICES).

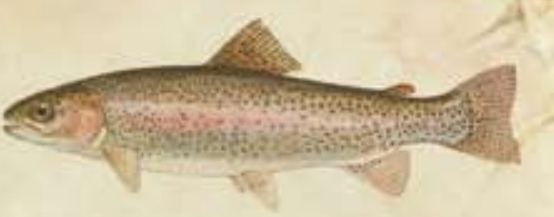

Rainbow trout

Oncorhynchus mykiss

Selection for reduced growth rate and less active/bold behaviour (experimental field populations: Biro and Post, 2008; source: US Fish and Wildlife Service).

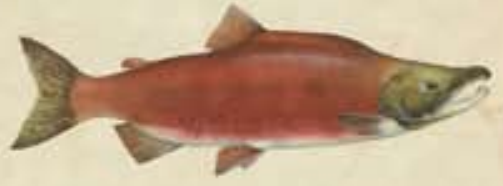

\section{Sockeye salmon}

Oncorhynchus nerka

Earlier run time (Bristol Bay, US: Quinn et al 2007; source: US Fish and Wildlife Service).

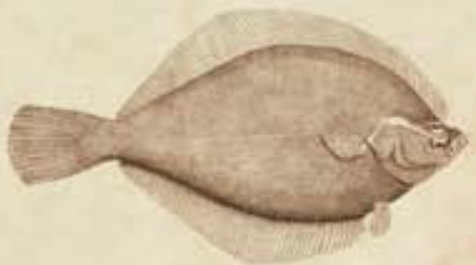

Yellowtail flounder

Limanda ferruginea

Maturation at younger age and smaller size (southern Gulf of St Lawrence, Scotian Shel Beacham, 1983e; source: NOAA).

$\Delta$ Observed trends suggestive of fishery-induced evolution. Based on Jørgensen et al., (2007) with modifications.

\section{Ulf Dieckmann, Mikko Heino, and Adriaan Rijnsdorp suggest that we are incurring a "Darwinian debt" that will have to be repaid by future fishers and consumers.}

\section{Looking back}

Let us compare a livestock farmer and a fisher. The farmer selects and breeds individuals that exhibit the most desirable characteristics. This is good practice, because it increases the prevalence of these characteristics in the next generation of the stock. In contrast, the fisher catches large, fast-growing fish, so their desirable characteristics are less likely to be passed on to the next generation of the stock.

Fish that grow quickly tend to be caught sooner and therefore may produce fewer offspring. Fish that delay maturation tend to be caught before they have the chance to reproduce, so the fish that are left to breed are those that mature at a younger age. Fish that limit their current investment in reproduction in order to increase future reproductive success will often be harvested before such savings have a chance to pay dividends. The mortality imposed by fishing can therefore act as a selective force that favours slower growth, earlier maturation, and higher reproductive investment.
Clearly, the selections made by the farmer and the fisher work in opposite directions. The farmer selects desired characteristics that improve his stock, whereas the fisher selects characteristics that may inadvertently reduce a stock's productivity and resilience. Therefore, fishery scientists need to incorporate both ecological processes and evolutionary processes in their research programmes in order to ensure the best scientific basis for fishery management.

The notion that fishing can affect the genetic composition of exploited populations has been recognized for a century. Perhaps the earliest account can be credited to Cloudsley Rutter (Rutter, 1904), a US salmon biologist, who warned more than a hundred years ago:

[A] stock-raiser would never think of selling his fine cattle and keeping only the runts to breed from.... The salmon will certainly deteriorate in size if the medium and larger sizes are taken for the markets and only the smaller with a few of the medium allowed to breed. 


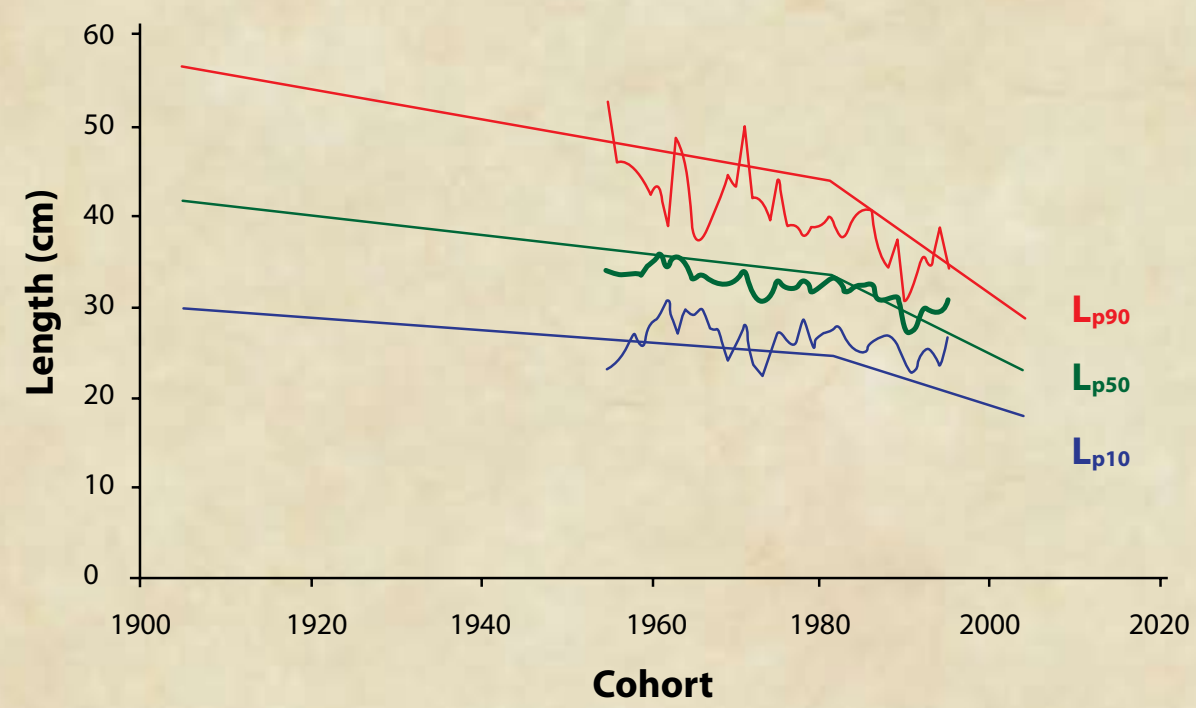

- Figure 1. Changes in the probabilistic maturation reaction norm (PMRN) of female North Sea plaice at the age of 4 years. The figure shows how the body lengths at which female plaice of this age mature have dropped precipitously throughout the 20th century (blue curves, 10\% probability; green curves, 50\% probability; red curves, 90\% probability.) Based on Grift et al. (2003; grey curves) and van Walraven et al. (2009; black curves).

Yet, it was not until the 1980s that decreasing trends in the age- and size-at-maturation of northeast Arctic cod and North Sea plaice renewed interest in this topic. In the UK, Richard Law explored the implications of fisheryinduced evolution for fishery yields, demonstrating that maturation evolution in response to fishing could reduce productivity (Law and Grey, 1989). In the Netherlands, Adriaan Rijnsdorp (Rijnsdorp, 1993a) analysed changes in maturation, reproductive investment, and growth in North Sea plaice in an attempt to quantify how much of the observed change in these life-history characteristics were caused by the environment and how much could be attributed to evolution.

\section{Stocks that become better adapted to fishing usually do so at the expense of becoming less well adapted to their "natural" environment.}

In ICES, the topic was discussed at a meeting of the Long-term Management Working Group in 1993, chaired by Kevin Stokes. From 1995 onwards, various working groups were given the task of reviewing the literature in this field. Intensified research, conducted since around 2000, led to theme sessions at the ICES Annual Science Conferences in 2002 and 2006 and the establishment of the ICES Study Group on Fisheries-Induced Adaptive Change (SGFIAC) in 2006. These activities, in turn, attracted more researchers to the field. Reviewing the evidence for fishery-induced evolution and discussing its implications for fishery management, the first SGFIAC report was summarized as a Policy Forum article in Science (Jørgensen et al., 2007).

\section{The evidence}

The available evidence for fishery-induced evolution stems from three different sources.

- time-series analysis of long-term field data on maturation, reproductive investment, and growth

- experiments in controlled laboratory environments

\section{- model-based studies}

The illustration on the first two pages of this article provides an overview of empirical findings suggestive of fishery-induced evolution across species and stocks (based on Jørgensen et al., 2007, with modifications).

A challenge in the analysis of time-series of field data is that observable life-history characteristics are influenced by environment and genetics. It is well known that similar genotypes can give rise to a broad variety of phenotypes, depending on the environment that individuals experience. Trends caused by such phenotypic plasticity have to be taken into account before residual trends can be interpreted as being indicative of genetic changes.

For the process of maturation, therefore, a method has been developed to account for the impacts of growthrelated phenotypic plasticity and survival changes (Heino et al., 2002a; Dieckmann and Heino, 2007). In this manner, maturation schedules (called probabilistic maturation reaction norms, or PMRNs) can be estimated that describe the probability of an individual reaching maturation at a given age and size, provided it has grown and survived to that age and size. A shift in the PMRN, 
summarized by changes in the length-at-age at which the maturation probability reaches $50 \%\left(\mathrm{~L}_{\mathrm{p} 50}\right)$, means that observed maturation trends cannot be explained by growth-related phenotypic plasticity and survival changes alone. If such a change is in line with predictions of lifehistory evolution (adaptation towards earlier maturation under exploitation), it supports the hypothesis of fisheryinduced evolution. Figure 1 shows the trend in $\mathrm{L}_{\mathrm{p} 50}$, for North Sea plaice females at the age of four years.

It should be noted that analyses of long-term field data cannot provide definite proof of evolutionary change, because it is always possible that the observed residual trends may have been caused by additional environmental factors that were not considered. Nevertheless, the broad consistency of observed PMRN trends across a variety of different fish species, stocks, and ecosystems, and the agreement of these trends with the predictions of general life-history theory and of more specific models, makes an evolutionary interpretation likely. Empirical support for fishery-induced evolution in other lifehistory characteristics, such as reproductive investment and growth, is more ambiguous, partly because the disentangling of phenotypic plasticity and genetics is more complicated.

Definite proof that fishing mortality leads to evolutionary changes comes from studies that manipulated mortality in experimental populations. In the US, David Reznick and colleagues (Reznick et al., 1993) demonstrated that differences in mortality led to differences in genetic lifehistory traits in guppies. David Conover and colleagues (Conover and Munch, 2002) exposed experimental laboratory populations of Atlantic silversides, a small pelagic species, to different types of size-dependent mortality and demonstrated a variety of genetic responses, as well as associated effects on yields.

Figure 2. The timing of maturation has a considerable influence on the size of females spawning for the first time (illustrated by the large fish above the red growth curves) and their expected reproductive success. The latter is determined by two components, relative clutch size (illustrated by clutches becoming larger as females grow) and probability of surviving to produce a clutch (illustrated by the fading colour of clutches). Which maturation age is evolutionarily favoured depends on natural mortalities and fishery mortalities (illustrated by gradients at the bottom and top of each panel). Top: In the absence of fishing, large fish face little mortality. Under such conditions, delayed maturation and growth to a large size are advantageous. Fishing turns this situation around by targeting large fish. Centre: Fish that delay maturation end up trying to reproduce at ages when they are at high risk of having been fished. Bottom: Fish that reproduce early and invest their resources in reproduction instead of growth are favoured by fishery-induced selection.

\section{Support from model-based studies}

Further support for fishery-induced evolution stems from model-based studies. These range from simple agestructured models (e.g. Law and Grey, 1989), to age- and size-structured models that account for growth-related maturation plasticity (Ernande et al., 2004), to eco-
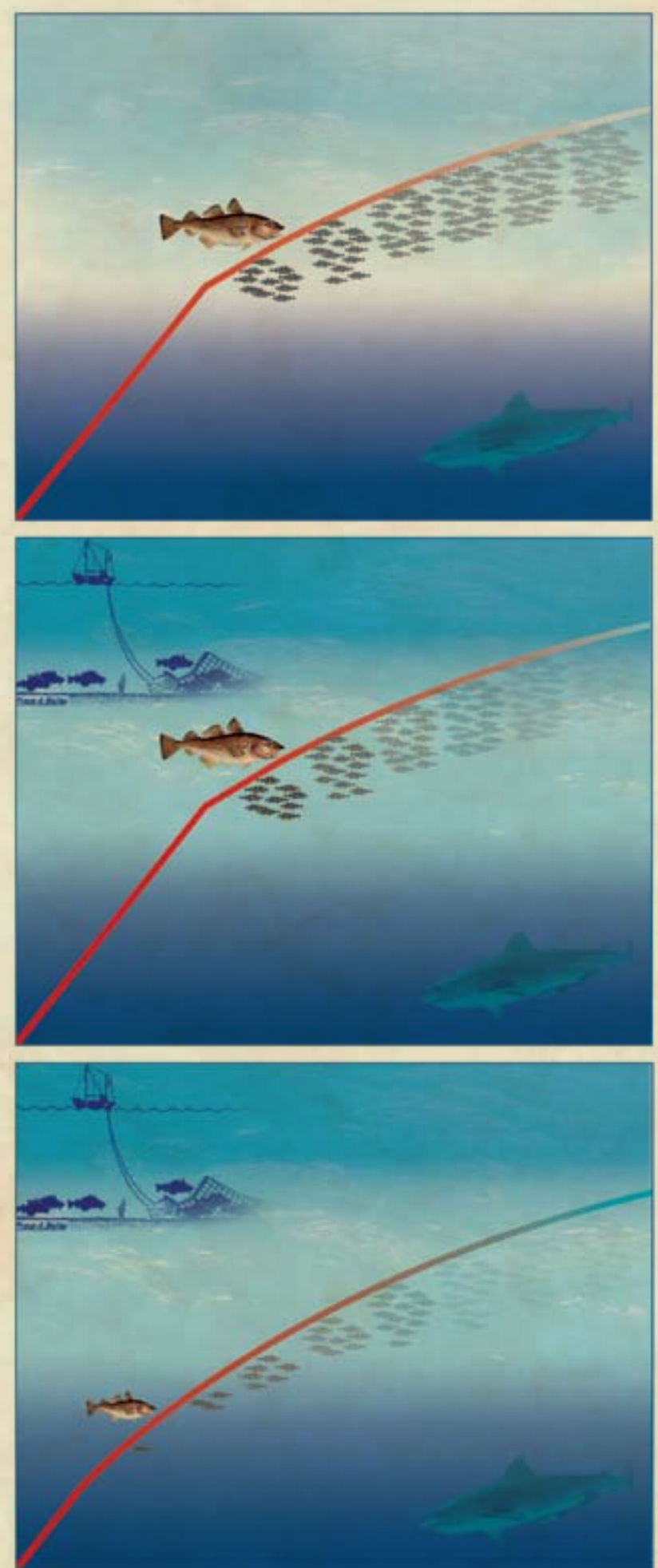
genetic models that combine the ecological processes of growth, maturation, reproduction, and survival with the quantitative genetics of the underlying life-history traits (Dunlop et al., 2009).

Although simpler models can help to corroborate expected directions of evolutionary responses to fishing, reliably estimating the pace of such adaptations requires models that are more advanced. To be credible, such models need to do sufficient justice to the ecological and evolutionary complexities of natural stock dynamics, and they should be based as closely as possible on empirical measurements. Models accounting for these requirements can then be used to forecast the direction, speed, and outcome of future fishery-induced evolution, thus revealing the evolutionary implications of current management regimes. Studies of this kind have demonstrated that the selection patterns of current fisheries can indeed lead to fishery-induced evolution over a decadal time-scale and that such changes do affect the productivity of stocks.

\section{Fishery managers must adjust fishing selectivity in order to minimize fishery-induced evolution for traits that are considered important without sacrificing too much yield.}

The utility of models for studying fishery-induced evolution goes further.

First, models can help us to understand past fisheryinduced evolution. In particular, they can provide a means of testing whether or not the observed life-history trends attributed to such adaptation are compatible with the selection pressures imposed by the life cycle of a stock and the fishing regime.

Second, fishery managers can use the information provided by models to support decisions regarding the prioritization of regulations and research. Specifically, a stock's evolutionary vulnerability differs with its current life history, the life-history trends that it may already have undergone, the amount of genetic variation that it currently harbours, and the detailed characteristics of its current fishing regime. These contingencies limit the value of one-size-fits-all models of fishery-induced evolution and, instead, underscore the importance of developing stock-specific models.

Third, and perhaps most importantly, models of fishery-induced evolution can assist fishery scientists and managers in the investigation of the evolutionary implications of alternative management scenarios. As changes in yield and sustainability depend on a complex interplay of life-history trends induced by fishing, responsible forecasts will often have to be model-based. In this regard, advanced models can be likened to flight simulators, allowing safe tinkering with a modelled stock, which would be far too costly or dangerous to implement without prior model-aided assessments.

\section{The good news/bad news}

Fishery-induced evolution is adaptation fishing, and the better adapted the fish, the more progeny it is likely to produce. This sounds positive, at least from the perspective of the fish, but it is not always the case.

An increased awareness and avoidance of fishing gear among fish can be regarded as an evolution-aided "escape" from fishing. The evolution of reduced adult body size can also be seen from this perspective because fish below the minimum legal landing size are typically less attractive fishing targets.

In contrast, fishery-induced evolution of traits such as maturation schedules can be interpreted as a means of coping with the inevitable: the primary effect of such changes is not a diminished exposure to fishing but the increased production of offspring under conditions of fishing.

In both cases, fish stocks that have adapted to fishing through evolution can be expected to be more resilient to fishing than those lacking such adaptations. This prediction is supported by recent model-based studies: fishery-induced adaptation allows populations to sustain greater fishing pressures than would be possible without such adaptation (see for example Heino, 1998; Enberg et al., 2009).

The advantage of enhanced resilience, however, comes at a cost. 
First, stocks that become better adapted to fishing usually do so at the expense of becoming less well adapted to their "natural" environment. In particular, populations may become less resilient to long-term variations in their environment. For example, a long lifespan is usually interpreted as an adaptation to unpredictable variations in recruitment success, but fisheries favour individuals that live fast and die young, as illustrated in Figure 2. Second, theoretical and empirical studies suggest that the effects of fishery-induced evolution on fishing yields are largely negative. Total biomass yield usually declines when fish redirect the investment of energy from body growth into reproduction. Consequently, a greater proportion of the catch will consist of small, and therefore less valuable, fish.

Third, fish that are forced to reproduce early in life often do so less successfully than their older conspecifics, making the same spawning stock size less valuable in terms of the stock's reproduction. For these reasons, fishery managers will often want to minimize fisheryinduced evolution.

\section{Turning it around}

What options are there for slowing or reversing unwanted fishery-induced evolution? Possible solutions fall into two categories.

First, reducing fishing effort, while keeping its selectivity unchanged, will almost certainly help to slow the pace of fishery-induced evolution. If the reduction is large enough, and conditions are especially favourable, the unwanted evolution might even be reversed. A reduction in fishing effort is often compatible with more traditional management goals: many fish stocks are overexploited, so, in the long term, reduced exploitation is likely to generate higher yields with lower costs and emissions and reduced ecosystem effects.

Second, changing the selectivity of fishing mortality is more likely to stop or reverse fishery-induced evolution, because - in principle - it allows fishery managers to fine-tune selection pressures to achieve this. Models are currently being developed to help fishery scientists and managers accomplish this.

A conceptually straightforward approach would be to make the size selectivity of fishing mortality similar to that of natural mortality. However, this simple strategy usually has two disadvantages.

First, when the size selectivity of fishing mortality matches that of natural mortality, the extra mortality resulting from fishing will continue to cause fishery- induced evolution. (At this point, it is helpful to recall that fully size-independent mortality still induces selection pressures, because such uniform mortality still devalues reproduction late in life.)

Second, as natural mortality is typically much greater for small fish than large fish, changing fishing selectivity to match such a pattern is liable to cause recruitment overfishing, which undermines yields.

Therefore, fishery managers need to adjust fishing selectivity in order to minimize fishery-induced evolution for traits that are considered important without sacrificing too much yield. How best to achieve this must be evaluated on a case-by-case basis, which will usually require the investigation of stock-specific models.

As long as some sacrifices are made, slowing down unwanted fishery-induced evolution is relatively straightforward. Reversing it is another matter. This is because reverse evolution would often have to rely on natural selection. Law and Grey (1989) have already suggested that natural selection for delayed maturation is relatively weaker than fishery-induced selection for earlier maturation.

This idea was corroborated by recent, more realistic models (Dunlop et al., 2009; Enberg et al., 2009), which demonstrate that the rate of evolutionary recovery is much lower than the rate of fishery-induced evolution. In other words, evolutionary "damage" usually occurs much faster than it can be repaired. Model results suggest that, for each year during which current exploitation patterns continue, several years of evolutionary recovery, under the best of conditions, may be required; this implies the build-up of a "Darwinian debt" that will have to be repaid by future fishers and consumers.

Given the social and political difficulties encountered when trying to implement major changes to current exploitation patterns, fishery-induced evolution could essentially be irreversible on time-scales that are of interest to fishery management (from years to a few decades). It seems self-evident that this observation should trigger the attention of managers subscribing to the precautionary approach to fisheries.

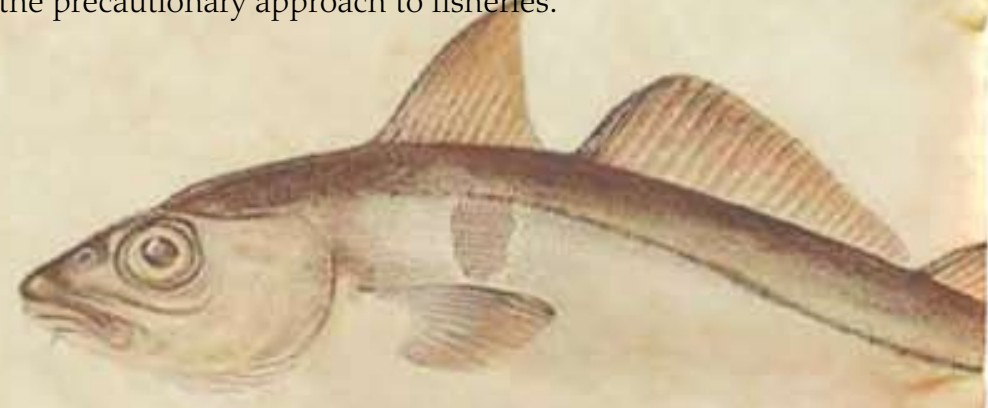




\section{Looking forward}

Despite the fact that evolutionary theory has been the cornerstone of biology since the publication of $\mathrm{On}$ the Origin of Species 150 years ago, the implications of Darwin's dangerous idea for fishery science have sparked a lively debate (Hilborn, 2006; Marshall and Browman, 2007; Kuparinen and Merilä, 2008). This debate does not so much question whether or not fishery-induced evolution occurs, but focuses on the strength of the empirical evidence and on the expected rate of fisheryinduced evolution.

Although there may be some residual scepticism within the community of fishery scientists, and although the practical implications of fishery-induced evolution have yet to be examined more closely, the evidence supporting the likely and widespread occurrence of fishery-induced evolution has become sufficiently strong that fishery scientists and managers can no longer ignore the evolutionary dimension of fisheries.

This conclusion agrees with the precautionary approach to fisheries (FAO, 1995), which prescribes the exercise of

...prudent foresight to avoid unacceptable or undesirable situations, taking into account that changes in fisheries systems are only slowly reversible, difficult to control, not well understood, and subject to change in the environment and human values.

This approach also requires managers of over-utilized fisheries to

...take immediate short-term action even on the basis of circumstantial evidence about the effectiveness of a particular measure.

In the long term, evidence for fishery-induced evolution is likely to be strengthened by modern genetic techniques based on the extraction and analysis of DNA sequences from historical otoliths or scales. Such approaches can document and quantify changes in gene frequencies over periods of several decades. In particular, changes in

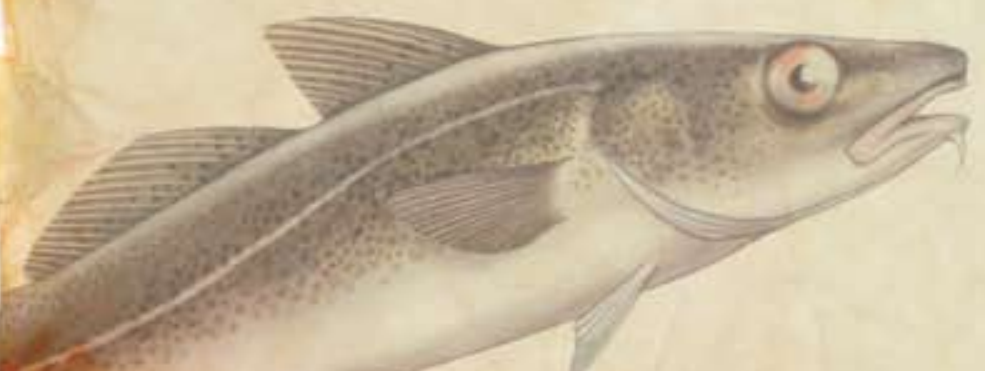

genes that are linked to life-history processes, such as growth, maturation, and reproduction, will be of interest. This does not mean, however, that we can expect to obtain definite proof of fishery-induced evolution by applying such techniques, because changes in gene frequencies may be caused either by fishery selection or by selection that is the result of other environmental factors, such as climate change.

Accordingly, the conclusive attribution of causal interpretations to correlative evidence is practically impossible for uncontrolled field observations, such as those obtained from fisheries. In addition, current knowledge of the full genetic underpinning of complex life-history processes, such as maturation, remains woefully incomplete. Therefore, for most species and stocks, it seems safe to assume that fishery scientists and managers must continue to rely on correlative phenotypic evidence for fishery-induced evolution for the next decade, if not longer. Mitigating actions cannot be postponed that long.

\section{Evolutionary "damage" usually occurs much faster than it can be repaired.}

Reflecting on the considerations above, we propose three courses of action.

First, the monitoring of salient life-history characteristics, such as growth rates, maturation schedules, and reproductive investments, should be integrated into routine stock assessments.

Second, stock-specific models need to be developed and calibrated that take into account the genetics as well as the ecological processes involved in the dynamics of the stock under exploitation.

Third, such calibrated stock-specific models should be used to explore and evaluate the implications of alternative patterns of fishery selection on the life history, productivity, and resilience of stocks.

This calls for close collaboration between life-history modellers and fishery scientists who assemble data and give management advice. We expect that case studies integrating the three components recommended here life-history monitoring, model calibration, and strategy evaluation - will provide useful examples of how fishery management can develop its long overlooked evolutionary dimension. 
Ulf Dieckmann is a theoretical ecologist interested in fishery-induced evolution, speciation research, life-history adaptations, spatial ecology, cooperation evolution, and adaptive dynamics theory. He leads the Evolution and Ecology Program at the International Institute for Applied Systems Analysis (IIASA), Austria.

Mikko Heino is a population biologist with a keen interest in life-history theory and fish. He leads the Evolutionary Fisheries Ecology research group at the University of Bergen, Norway. He is also a scientist at the Institute of Marine Research in Bergen and at IIASA in Austria.

\section{Effects of fishery-induced evolution reference points}

on

Biological reference points quantify limits between desirable and undesirable states in fishery systems. Typically, reference points describe either the status of a stock (e.g. spawning-stock biomass, or SSB) or the pressure exerted on a stock (e.g. fishing mortality). To account for uncertainty, reference points are often set on a precautionary basis. Good reference points are insensitive to short-term variability of a fishery system, but may require adjustment when long-term changes in a fish stock or its fishery are taking place, for example, as a result of climate change.

ICES Study Group on Fisheries-Induced Adaptive Change (SGFIAC) is preparing an article entitled "Can fisheriesinduced evolution shift reference points for fisheries management?" This explores two routes by which fisheryinduced evolution may affect reference points, namely:

(i) by biasing the estimates of the indicators on which reference points are based (e.g. by biasing SSB estimates) and/or

(ii) by changing a stock's dynamics (e.g. by changing the SSB-recruitment relationship).

Changes along either route might result in a shift of a reference point. In one direction, a reference point might become more precautionary than intended, but the error will be on the side of safety. On the other hand, and more troubling, a reference point might be shifted in the direction of higher risk, thereby giving a false sense of security. Which of these outcomes is more likely depends on the reference point and on the details of the fish stock and its fishery.
Adriaan Rijnsdorp is a senior scientist at the Institute for Marine Resources and Ecosystem Studies (IMARES, IJmuiden, the Netherlands) with a special focus on the dynamics of fish populations, fishers, and ecosystems, and holds a special chair in Sustainable Fisheries Management at Wageningen University, the Netherlands.

The ICES Study Group on Fishery-Induced Adaptive Change (SGFIAC), chaired by the authors, has benefited from participation by the following researchers: Robert Arlinghaus, Loïc Baulier, David Boukal, Dorothy Dankel, Erin Dunlop, Anne Maria Eikeset, Katja Enberg, Georg Engelhard, Bruno Ernande, Anna Gårdmark, Fiona Johnston, Christian Jorgensen, Laurence Kell, Ane Laugen, Lise Marty, Shuichi Matsumura, Fabian Mollet, Sébastien Nusslé, Heidi Pardoe, Jan Jaap Poos, Kristina Raab, Alexandra Silva, Nina Therkildsen, Davnah Urbach, Silva Uusi-Heikkilä, Anssi Vainikka, Ingrid Wathne, Rebecca Whitlock, and Fabian Zimmermann.

For more information, visit SGFIAC's web page at the ICES website: www.ices.dk/workinggroups/ViewWorkingGroup.aspx?ID=203.

\section{Evolutionary impact assessment}

Fishery-induced evolution may change the utility of fish stocks, e.g. by altering utility components such as fishery yields, stock stability, recovery potential, trophic interactions, geographical distributions, genetic diversity, benefits to tourism, and the intrinsic values of species and ecosystems. Such changes modify the ecosystem services through which living aquatic resources provide value to society. Therefore, quantifying and characterizing the evolutionary effects of fishing is important for both economic and ecological reasons.

ICES Study Group on Fisheries-Induced Adaptive Change (SGFIAC) is preparing an article titled "Evolutionary impact assessment: accounting for evolutionary consequences of fishing in an ecosystem approach to fishery management". This describes evolutionary impact assessment (EvolA; Jørgensen et al., 2007) as a set of methods for assessing the evolutionary consequences of fishing and for evaluating the merits of alternative management options. This set of methods will:

(i) contribute to the ecosystem approach to fishery management by clarifying how evolution alters stock properties and ecological relationships;

(ii) support the precautionary approach to fishery management by addressing a previously overlooked source of uncertainty and risk;

(iii)help to realize the Johannesburg World Summit's commitment to the restoration of sustainable fisheries by helping fishery managers to cope with the evolutionary implications of fishing. 


\section{Literature cited}

Barot, S., Heino, M., O'Brien, L., and Dieckmann, U. 2004. Long-term trend in the maturation reaction norm of two cod stocks. Ecological Applications, 14: 1257-1271.

Barot, S., Heino, M., Morgan, M. J., and Dieckmann, U. 2005. Maturation of the Newfoundland American plaice (Hippoglossoides platessoides): long-term trends in maturation reaction norms despite low fishing mortality? ICES Journal of Marine Science, 62: 56-64.

Baulier, L., Heino, M., Lilly, G. R., and Dieckmann, U. 2006. Body condition and evolution of maturation of Atlantic cod in Newfoundland. ICES Document CM 2006/H:19. 11 pp.

Beacham, T. D. 1983a. Growth and maturity of Atlantic cod (Gadus morhua) in the southern Gulf of St. Lawrence. Canadian Technical Report of Fisheries and Aquatic Sciences, 1142. 31 pp.

Beacham, T. D. 1983b. Variability in median size and age at sexual maturity of Atlantic cod, Gadus morhua, on the Scotian Shelf in the Northwest Atlantic Ocean. Fisheries Bulletin US, 81: 303-321.

Beacham, T. D. 1983c. Variability in size and age at sexual maturity of haddock (Melanogrammus aeglefinus) on the Scotian Shelf in the Northwest Atlantic. Canadian Technical Report of Fisheries and Aquatic Sciences, 1168.33 pp.

Beacham, T. D. 1983d. Variability in size and age at sexual maturity of argentine, Argentina silus, on the Scotian Shelf in the Northwest Atlantic Ocean. Environmental Biology of Fishes, 8: 67-72.

Beacham, T. D. 1983e. Variability in size and age at sexual maturity of American plaice and yellowtail flounder in the Canadian Maritimes Region of the Northwest Atlantic Ocean. Canadian Technical Report of Fisheries and Aquatic Sciences, 1196.75 pp.

Beacham, T. D. 1983f. Variability in size and age at sexual maturity of witch flounder, Glyptocephalus cynoglossus, in the Canadian Maritimes Region of the Northwest Atlantic Ocean. Canadian Field Naturalist, 97: 409-422.

Bielak, A. T., and Power, G. 1986. Changes in mean weight, sea-age composition, and catch-per-unit-effort of Atlantic salmon (Salmo salar) angled in the Godbout River, Quebec, 1859-1983. Canadian Journal of Fisheries and Aquatic Sciences, 43: 281-287.

Biro, P. A., and Post, J. R. 2008. Rapid depletion of genotypes with fast growth and bold personality traits from harvested fish populations. Proceedings of the National Academy of Sciences of the USA, 105: 2919 2922.

Cardinale, M., and Modin, J. 1999. Changes in size-at-maturity of Baltic cod (Gadus morhua) during a period of large variations in stock size and environmental conditions. Fisheries Research, 41: 285-295.

Conover, D. O., and Munch, S. B. 2002. Sustaining fisheries yields over evolutionary time scales. Science, 297: 94-96.

Consuegra, S., García de Leániz, C., Serdio, A., and Verspoor, E. 2005. Selective exploitation of early running fish may induce genetic and phenotypic changes in Atlantic salmon. Journal of Fish Biology, 67(Suppl. A): $129-145$

Cooke, S. J., Suski, C. D., Ostrand, K. G., Wahl, D. H., and Philipp, D. P. 2007. Physiological and behavioral consequences of long-term artificial selection for vulnerability to recreational angling in a teleost fish. Physiological and Biochemical Zoology, 80: 480-490.
Dieckmann, U., and Heino, M. 2007. Probabilistic maturation reaction norms: their history, strengths, and limitations. Marine Ecology Progress Series, 335: 253-269.

Dieckmann, U., Heino, M., and Jin, X. 2005. Shrinking fish: fisheriesinduced evolution in the Yellow Sea. Options, Autumn 2005: 8.

Drake, M. T., Claussen, J. E., Philipp, D. P., and Pereira, D. L. 1997. A comparison of bluegill reproductive strategies and growth among lakes with different fishing intensities. North American Journal of Fisheries Management, 17: 496-507.

Dunlop, E. S., Heino, M., and Dieckmann, U. 2009. Eco-genetic modeling of contemporary life-history evolution. Ecological Applications, 19(7): 000-000.

Enberg, K., Dunlop, E. S., Jørgensen, C., Heino, M., and Dieckmann, U. 2009. Implications of fisheries-induced evolution for stock rebuilding and recovery. Evolutionary Applications, 2: 394-414.

Engelhard, G. H., and Heino, M. 2004. Maturity changes in Norwegian spring-spawning herring before, during, and after a major population collapse. Fisheries Research, 66: 299-310.

Ernande, B., Dieckmann, U., and Heino, M. 2004. Adaptive changes in harvested populations: plasticity and evolution of age and size at maturation. Proceedings of the Royal Society of London, Series B, 271: 415-423.

FAO. 1995. Precautionary approach to fisheries. Part 1: Guidelines on the precautionary approach to capture fisheries and species introductions. FAO Fisheries Technical Paper 350, Part 1.54 pp.

Grift, R. E., Rijnsdorp, A. D., Barot, S., Heino, M., and Dieckmann, U. 2003. Fisheries-induced trends in reaction norms for maturation in North Sea plaice. Marine Ecology Progress Series, 257: 247-257.

Grift, R. E., Heino, M., Rijnsdorp, A. D., Kraak, S. B. M., and Dieckmann U. 2007. Three-dimensional maturation reaction norms for North Sea plaice. Marine Ecology Progress Series, 334: 213-224.

Handford, P., Bell, G., and Reimchen, T. 1977. A gillnet fishery considered as an experiment in artificial selection. Journal of the Fisheries Research Board of Canada, 34: 954-961.

Harris, P. J., and McGovern, I. C. 1997. Changes in the life history of red porgy, Pagrus pagrus, from the southeastern United States, 1972-1994. Fishery Bulletin US, 95: 732-747.

Haugen, T. O., and Vøllestad, L. A. 2001. A century of life-history evolution in grayling. Genetica, 112-113: 475-491.

Heino, M. 1998. Management of evolving fish stocks. Canadian Journal of Fisheries and Aquatic Sciences, 55: 1971-1982.

Heino, M., Dieckmann, U., and Godø, O. R. 2002a. Measuring probabilistic reaction norms for age and size at maturation. Evolution, 56: 669-678.

Heino, M., Dieckmann, U., and Godø, O. R. 2002b. Reaction norm analysis of fisheries-induced adaptive change and the case of the northeast Arctic cod. ICES Document CM 2002/Y: 14. 14 pp.

Hilborn, R. 2006. Faith-based fisheries. Fisheries, 31: 554-555.

Jørgensen, C., Enberg, K., Dunlop, E. S., Arlinghaus, R., Boukal, D. S. Brander, K., Ernande, B., et al. 2007. Managing evolving fish stocks. Science, 318: 1247-1248. 
Kuparinen, A., and Merilä, J. 2008. The role of fisheries-induced evolution. Science, 320: 47-48 (Letter).

Law, R., and Grey, D. R. 1989. Evolution of yields from populations with age-specific cropping. Evolutionary Ecology, 3: 343-359.

Magnan, P., Proulx, R., and Plante, M. 2005. Integrating the effects of fish exploitation and interspecific competition into current life history theories: an example with lacustrine brook trout (Salvelinus fontinalis) populations. Canadian Journal of Fisheries and Aquatic Sciences, 62 747-757.

Marshall, C. T., and Browman, H. I. 2007. Theme section: disentangling the causes of maturation trends in exploited fish populations. Marine Ecology Progress Series, 335: 249-310.

Mollet, F. M., Kraak, S. B. M., Rijnsdorp, A. D. 2007. Fisheries-induced evolutionary changes in maturation reaction norms in North Sea sole Solea solea. Marine Ecology Progress Series, 351: 189-199.

Olsen, E. M., Heino, M., Lilly, G. R., Morgan, M. J., Brattey, J., Ernande, B., and Dieckmann, U. 2004. Maturation trends indicative of rapid evolution preceded the collapse of northern cod. Nature, 428: 932-935.

Olsen, E. M., Lilly, G. R., Heino, M., Morgan, M. J., Brattey, J., and Dieckmann, U. 2005. Assessing changes in age and size at maturation in collapsing populations of Atlantic cod (Gadus morhua). Canadian Journal of Fisheries and Aquatic Sciences, 62: 811-823.

Polovina, J. J. 1989. Density dependence in spiny lobster, Panulirus marginatus, in the northwestern Hawaiian Islands. Canadian Journal of Aquatic and Fisheries Science, 46: 660-665.

Quinn, T. P., Hodgson, S., Flynn, L., Hilborn, R., and Rogers, D. E. 2007. Directional selection by fisheries and the timing of sockeye salmon (Oncorhynchus nerka) migrations. Ecological Applications, 17: 731739.

Reznick, D. A., Bryga, H., and Endler, J. A. 1990. Experimentally induced life-history evolution in a natural population. Nature, 346: 357-359.

Reznick, D. N., and Ghalambor, C. K. 2005. Can commercial fishing cause evolution? Answers from guppies (Poecilia reticulata). Canadian Journal of Fisheries and Aquatic Sciences, 62: 791-801.

Reznick, D. N., Bryga, H., and Endler, J. A. 1993. Experimentally induced life-history evolution in a natural population. Nature, 346: 357-359.

Ricker, W. E. 1981. Changes in the average size and average age of Pacific salmon. Canadian Journal of Fisheries and Aquatic Sciences, 38: 16361656.

Ricker, W. E. 1995. Trends in the average size of Pacific salmon in Canadian catches. Canadian Special Publication of Fisheries and Aquatic Sciences, 121: 593-602.

Rijnsdorp, A. D. 1989. Maturation of male and female North Sea plaice (Pleuronectes platessa L.). Journal $d u$ Conseil International pour l'Exploration de la Mer, 46: 35-51.

Rijnsdorp, A. D. 1991. Changes in fecundity of female North Sea plaice (Pleuronectes platessa L.) between three periods since 1900. ICES Journal of Marine Science, 48: 253-280.

Rijnsdorp, A. D. 1993a. Fisheries as a large-scale experiment on lifehistory evolution: disentangling phenotypic and genetic effects in changes in maturation and reproduction of North Sea plaice, Pleuronectes platessa L. Oecologia, 96: 391-401.
Rijnsdorp, A. D. 1993b. Selection differentials in male and female North Sea plaice and changes in maturation and fecundity. In The Exploitation of Evolving Resources, pp. 19-36. Ed. by T. K. Stokes, J. M. McGlade, and R. Law. Springer-Verlag, Berlin. 264 pp.

Rijnsdorp, A. D., Grift, R. E., and Kraak, S. B. M. 2005. Fisheriesinduced adaptive change in reproductive investment in North Sea plaice (Pleuronectes platessa)? Canadian Journal of Fisheries and Aquatic Sciences, 62: 833-843.

Rutter, C. 1904. Natural history of the quinnat salmon. A report on investigations in the Sacramento River, 1886-1901. Bulletin of the United States Fish Commission, 22: 65-141.

Silliman, R. P. 1975. Selective and unselective exploitation of experimental populations of Tilapia mossambica. Fishery Bulletin US, 73: 495-507.

Swain, D.P., Sinclair, A. F., and Hanson, J. M. 2007. Evolutionary response to size-selective mortality in an exploited fish population. Proceedings of the Royal Society of London, Series B, 274: 1015-1022.

Templeman, W., and Bishop, C. A. 1979. Sexual maturity and spawning in haddock, Melanogrammus aeglefinus, of St. Pierre Bank. International Commission for the Northwest Atlantic Fisheries Research Bulletin, 14: $77-83$.

Templeman, W., Hodder, V. M., and Wells, R. 1978. Sexual maturity and spawning in haddock, Melanogrammus aeglefinus, of the southern Grand Bank. International Commission for the Northwest Atlantic Fisheries Research Bulletin, 13: 53-65.

Thomas, G., and Eckmann, R. 2007. The influence of eutrophication and population biomass on common whitefish (Coregonus lavaretus) growth: the Lake Constance example revisited. Canadian Journal of Fisheries and Aquatic Sciences, 64: 402-410.

Thomas, G., Quoss, H., Hartmann, J., and Eckmann, R. 2009. Humaninduced changes in the reproductive traits of Lake Constance common whitefish (Coregonus lavaretus). Journal of Evolutionary Biology, 22: 88-96.

Vainikka, A., Gårdmark, A., Bland, B., and Hjelm, J. 2009. Two- and three-dimensional maturation reaction norms for the eastern Baltic cod, Gadus morhua. ICES Journal of Marine Science, 66: 248-257.

van Walraven, L., Mollet, F. M., van Damme, C. J. G., and Rijnsdorp, A. D. 2009. Fisheries-induced evolution in growth, maturation and reproductive investment of the sexually dimorphic North Sea plaice (Pleuronectes platessa L.). Journal of Sea Research, doi:10.1016/j. seares.2009.07.003

Walsh, M. R., Munch, S. B., Chiba, S., and Conover, D. O. 2006. Maladaptive changes in multiple traits caused by fishing: impediments to population recovery. Ecology Letters, 9: 142-148.

Wohlfarth, G., Moav, R., and Hulata, G. 1975. Genetic differences between the Chinese and European races of the common carp. II. Multicharacter variation - a response to the diverse methods of fish cultivation in Europe and China. Heredity, 34: 341-350.

Wright, P. J. 2005. Temporal and spatial variation in reproductive investment of haddock in the North Sea. ICES Document CM 2005/Q:07. $24 \mathrm{pp}$.

Yoneda, M., and Wright, P. J. 2004. Temporal and spatial variation in reproductive investment of Atlantic cod Gadus morhua in the northern North Sea and Scottish west coast. Marine Ecology Progress Series, 276: 237-248. 